\title{
IMPLEMENTASI KEBIJAKAN PEMBANGUNAN PARIWISATA KABUPATEN KATINGAN, PROVINSI KALIMANTAN TENGAH
}

\author{
Emelyn Novalisa', Syamsul Alam Paturusi ${ }^{2}$, \\ Dewa Putu Oka Prasiasa3 \\ 1, 2 Universitas Udayana, ${ }^{3}$ Sekolah Tinggi Ilmu Manajemen Indonesia Handayani Denpasar \\ Email lisa.emelynnova@yahoo.com
}

\begin{abstract}
This study was conducted to identify and describe the regulation making processes and the implementation of the policy by the Local Government of Katingan Regency in managing the tourism potential resources through the development planning of the regency programs. The descriptive method with qualitative approach was applied with the application of qualititative data collection techniques. Data were collected through observation, structured-in depth interviews, and literature study, with primary data collection techniques were interviews of 14 of the key informants and the document review. The participants were selected due to the purposive qualitative sampling technique. The research showed the existing condition of the tourism in Katingan Regency which include the descriptions of the potential resources and the descriptions of the policy procession making by Badan Perencanaan Pembangunan Penelitian dan Pengembangan and the implementation of the regulation by Dinas Kebudayaan Pariwisata Pemuda dan Olahraga Kabupaten Katingan. The results of the research suggested that alternative regulation as an operational policy are needed to improve the development programs such as the management of resources policy and the sites management policy.
\end{abstract}

Keywords: development, policy, Local Authorities, resource management, Central Kalimantan.

\begin{abstract}
Abstrak
Penelitian ini merupakan kajian terhadap kebijakan Pemerintah Kabupaten Katingan dalampembangunan sektorkepariwisataan daerah sesuai kewenangannya dalam pelaksanaan otonomi daerah. Pengumpulan data dilakukan dengan teknik wawancara mendalam, observasi lapangan dan studi dokumentasi. Informan penelitian berjumlah 14 orang yang dipilih dengan teknik purposive sampling. Data yang dikumpulkan dianalisis
\end{abstract}


dengan teknik analisis deskriptif kualitatif yang ditunjang dengan analisis RIA (Regulatory Impact Analysis). Hasil penelitian mengungkapkan mengenai bentuk, mekanisme dan pertanggung jawaban dalam pembuatan kebijakan Rencana Induk Pembangunan Pariwisata Daerah sebagai kebijakan umum yang dilakukan oleh Badan Perencanaan Pembangunan Penelitian dan Pengembangan Kabupaten Katingan, sementara itu untuk Pelaksanaan Kebijakan menjadi tanggung jawab Dinas Kebudayaan Pariwisata Pemuda dan Olahraga Kabupaten Katingan. Hasil analisis data menggunakan RIA menunjukkan kebutuhan akan perlunya kebijakan teknis sebagai perwujudan dari kebijakan umum yang sudah dibuat yang menghasilkan model/ rancangan kebijakan alternatif berupa kebijakan pengelolaan potensi sumber daya dan kebijakan penataan kawasan.

Kata kunci: kebijakan pembangunan, kewenangan Pemerintah Daerah, pengelolaan potensi, Kalimantan Tengah

\section{Latar Belakang}

Undang-Undang tentang Pemerintahan Daerah yang sudah diubah beberapa kali, terakhir melalui Undang-Undang Nomor 23 Tahun 2014 tentang Pemerintahan Daerah mengamanatkan kewenangan khusus lembaga daerah yang dikenal dengan istilah otonomi daerah. Kewenangan ini memberikan keleluasaan bagi pemerintah daerah dalam mengurus sendiri urusan rumah tangganya untuk meningkatkan kesejahteraan masyarakat daerahnya, sesuai dengan kemampuan dan potensi yang dimiliki (Rasyid, 2002:9). Implikasi dari berkembangnya konsep otonomi dalam pelaksanaan pembangunan daerah yaitu bahwa pemerintah daerah memiliki kewenangan untuk mengolah, memanfaatkan, dan mengelola setiap aset dan sumber daya daerah yang potensial untuk diberdayakan agar dapat memberikan kontribusi nyata bagi perkembangan daerah dan peningkatan taraf hidup masyarakat. Pemerintah daerah diarahkan agar mampu menentukan sektor-sektor strategis yang dapat mendorong terlaksananya pembangunan di daerah.

Sektor pariwisata merupakan salah satu sektor prioritas dalam pembangunan di Indonesia saat ini karena memiliki prospek yang sangat besar untuk dikembangkan (Pitana \& Gayatri, 2005: 54), secara khusus bagi daerah-daerah di Indonesia yang menyimpan potensi kekayaan alam dan budaya yang melimpah dan beragam, yang layak untuk dijadikan sebagai daya tarik wisata, termasuk di Kabupaten Katingan. Pemerintah Kabupaten Katingan turut serta melaksanakan pembangunan sektor pariwisata daerah 
mengingat potensi pariwisata di Kabupaten Katingan yang cukup banyak dan beragam meliputi: (1) potensi wisata alam (antara lain seperti bukit, danau, sungai, air terjun, air panas alami, hutan, taman alam, kebun raya), (2) potensi wisata budaya (ragam kesenian dan upacara/ ritual adat), (3) situs sejarah, desa tradisional dan sentra kerajinan rakyat, serta potensi wisata minat khusus (Renstra Disbudparpora Kabupaten Katingan, 2008). Selain itu pembangunan sektor pariwisata diarahkan sebagai pembangunan yang tidak hanya menekankan keuntungan dari aspek ekonomi yang berpeluang membahayakan keberlangsungan sumber daya, akan tetapi pembangunan diarahkan agar adil bagi sosial budaya masyarakat dengan penekanan pada pelestarian lingkungan sehingga menjadikannya sebagai suatu upaya pembangunan yang layak untuk dilakukan di masa sekarang dan yang akan datang.

Undang-Undang Nomor 10 Tahun 2009 tentang Kepariwisataan mengatur mengenai peluang pemanfaatan dan pengembangan sumber daya pariwisata yang menjadi tanggung jawab semua pihak terkait, khususnya lembaga pemerintahan daerah yang bertanggung jawab atas setiap aset dan sumber daya daerah. Ketentuan perundang-undangan tersebut ditunjang dengan Rencana Induk Pembangunan Pariwisata Nasional (RIPPARNAS) yang selanjutnya menjadi pedoman bagi setiap daerah dalam merumuskan dan menyusun kebijakan pembangunan pariwisata sesuai karakteristik dan potensi daerah. Idealnya kebijakan pembangunan pada level daerah tidak hanya dijadikan sebagai bentuk ketaatan administratif lembaga daerah dalam pelaksanaan birokrasi pemerintahan tetapi juga merupakan bentuk pemahaman terhadap kebutuhan dan kapasitas daerah yang dituangkan melalui kebijakan pembangunan, sehingga kebijakan tersebut merupakan kebijakan yang dapat dilaksanakan dengan bertanggungjawab sesuai dengan prinsip-prinsip pembangunan.

Untuk menunjang pembangunan pariwisata di Kabupaten Katingan, pemerintah daerah telah melakukan suatu upaya strategis dengan membuat kebijakan berupa Rencana Induk Pembangunan Pariwisata Daerah (RIPPDA) yang diharapkan dapat mendorong terlaksananya pembangunan sektor kepariwisataan daerah agar dapat memberikan kontribusi positif bagi daerah. Akan tetapi sampai dengan saat ini pembangunan pariwisata di Kabupaten Katingan belum dapat terlaksana sesuai harapan, selain itu juga daerah masih memiliki banyak keterbatasan dalam berbagai aspek, terkhusus yang terkait dengan fasilitas pendukung kepariwisataan daerah, seperti infrastruktur dan aksesibilitas. Pemerintah daerah merupakan pihak yang memiliki kewenangan untuk menangani permasalahan tersebut melalui berbagai kebijakan dan upaya pembangunan yang dilakukan sebagai bentuk komitmen pemerintah daerah dalam mencapai sasaran pembangunan pada era otonomi. 
Berdasarkan kondisi tersebut, maka dilakukan penelitian yang ditujukan untuk (1) mendeskripsikan mengenai proses pembuatan kebijakan pembangunan pariwisata di Kabupaten Katingan berikut kendala-kendala yang dihadapi dalam prosesnya; (2) mendeskripsikan dan menganalisis pelaksanaan/ implementasi kebijakan pembangunan pariwisata di Kabupaten Katingan dalam kaitannya dengan upaya pembangunan yang dilakukan oleh pemerintah daerah, serta; (3) menyusun model kebijakan alternatif sebagai rekomendasi untuk mendukung pembangunan pariwisata berkelanjutan di Kabupaten Katingan.

\section{Teori dan Metode}

Kewenangan pemerintah dalam negara hukum yang menggunakan asas legalitas dalam konstitusinya sebagaimana yang tertuang dalam pasal 1 ayat 3 UUD 1945 perubahan ketiga mengandung arti bahwa penyelenggaraan pemerintahan harus didasarkan pada undang-undang dan memberikan jaminan terhadap hak-hak dasar rakyat. Perencanaan pembangunan merupakan salah satu bentuk pelaksanaan kewenangan pemerintah dan merupakan roh dari segala bentuk dan upaya pembangunan yang dimulai dari pembuatan kebijakan sebagai arahan dalam pembangunan (Conyers \& Hilss, 1990:3). Perencanaan pembangunan daerah meliputi seluruh sektor pembangunan yang kewenangannya telah diserahkan kepada daerah, termasuk salah satunya adalah sektor pariwisata. Dalam penyelenggaraan urusan pemerintahan tersebut, pemerintah daerah harus mampu untuk menyusun perencanaan strategis yang sistematis, komprehensif dan aspiratif untuk dapat mewujudkan visi dan misi pembangunan daerah untuk kemajuan daerah melalui kebijakan-kebijakan yang dibuat demi kepentingan umum (Munir, 2002:19). Kebijakan dapat dikatakan sebagai kebijakan yang efektif apabila mampu memenuhi kebutuhan dan harapan masyarakat lokal, lingkungan fisik dan sosial budaya, penanaman modal baik domestik dan internasional (Conlin dan Baum, 1995:6).

Kebijakan publik memusatkan perhatian pada apa yang sebenarnya perlu untuk dilakukan oleh pemerintah melalui berbagai alternatif penentuan langkah yang strategis untuk mencapai sasaran pembangunan (Easton dalam Agustino, 2009: 19). Dunn (2001: 35) mengemukakan bahwa analisis kebijakan publik merupakan sebuah disiplin ilmu sosial terapan yang menggunakan berbagai metode penelitian dan argumen untuk menghasilkan informasi yang relevan dengan kebijakan sehinga bisa dimanfaatkan dalam rangka memecahkan masalah yang terkait dengan implementasi kebijakan. Kebutuhan akan pembangunan yang memadai bagi kepentingan daerah beserta sumber daya yang digunakan dalam pembangunan merupakan pokok perhatian pemerintah dalam perumusan dan pelaksanaan kebijakan, sehingga kebijakan yang dihasilkan diharapkan dapat mengakomodir 


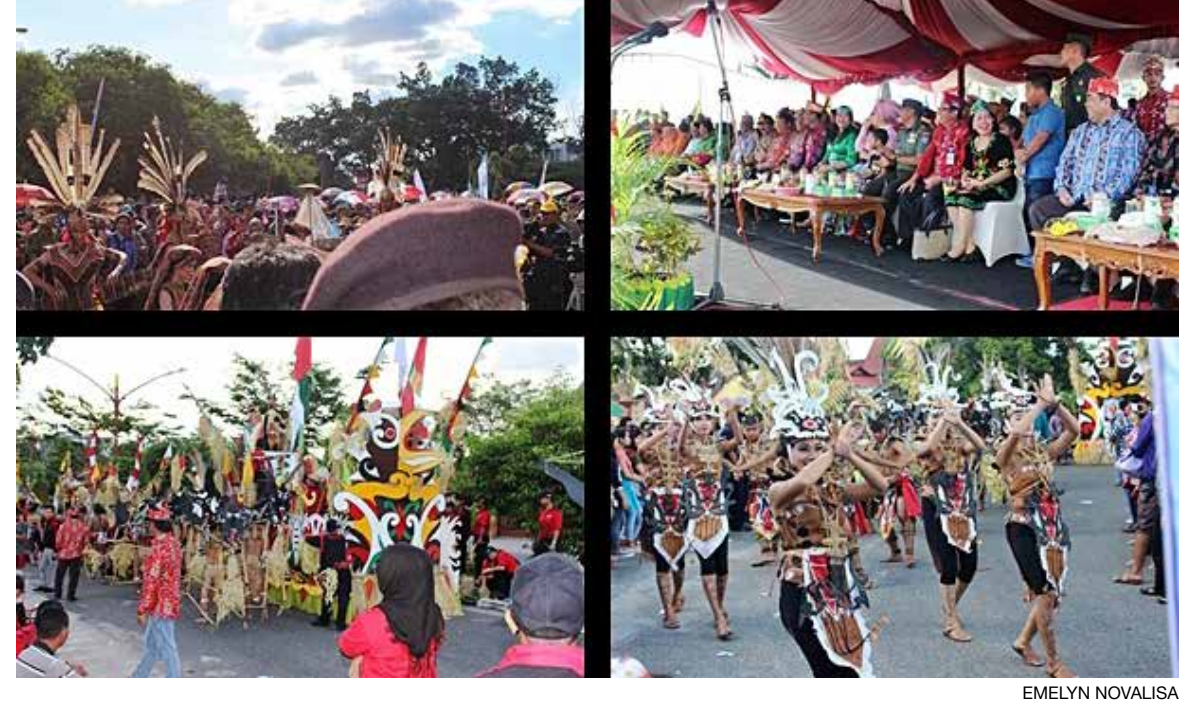

Foto 1. Festival Budaya Penyang Hinje Simpei sebagai potensi wisata budaya.

kepentingan-kepentingan umum serta berkeadilan bagi sumber daya sesuai dengan konsep pembangunan yang berkelanjutan (McKercher dalam Brokaj, 2014: 105). Pembangunan sektor pariwisata yang sejalan dengan pola pembangunan berkelanjutan tidak akan dapat terlaksana tanpa didukung oleh perencanaan pembangunan dan kebijakan yang sesuai, oleh karena itu melalui analisis kebijakan dilakukan penilaian terhadap kebijakan yang ada terkait kemampuannya dalam menjawab kebutuhan dalam pelaksanaan pembangunan (Wilkinson dalam Glorica, 2012: 141).

Untuk memperoleh jawaban dari permasalahan yang diteliti sesuai dengan tujuan penelitian, metode penelitian yang digunakan adalah penelitian deskriptif kualitatif yang mengutamakan pengamatan dan teknik wawancara mendalam dalam pengumpulan data dan informasi untuk mengeksplorasi topik yang diteliti. Penelitian dilakukan di Kabupaten Katingan, Provinsi Kalimantan Tengah, pada bulan Januari-Maret, 2017. Pengambilan data utama berasal dari instansi yang terkait dengan perencanaan pembangunan daerah dan pembuatan kebijakan seperti Badan Perencanaan Pembangunan Penelitian dan Pengembangan (BAPPELITBANG), instansi yang menangani sektor pariwisata daerah yaitu Dinas Kebudayaan Pariwisata Pemuda dan Olahraga Kabupaten Katingan serta instansi maupun unsur terkait lainnya.

Pengumpulan data dilakukan dengan wawancara mendalam, studi pustaka dan observasi. Sumber data diperoleh secara langsung melalui orangorang atau informan yang secara sengaja (purposive) dipilih karena diyakini layak (memenuhi persyaratan) dan memiliki relevansi yang kuat dengan permasalahan penelitian. Setiap informan yang diwawancarai dibuatkan daftar pertanyaan sesuai dengan kapasitas dan informasi yang dibutuhkan. Jumlah informan kunci dalam penelitian ini adalah 14 orang yang berasal dari kalangan birokrat (aparatur pemerintah daerah), tokoh masyarakat maupun pelaku usaha wisata di Kabupaten Katingan. Dokumentasi penelitian berupa peta lokasi penelitian, dokumen kebijakan atau produk hukum yang sudah 
dibuat, dokumen rencana pembangunan dan tata ruang, draft/rancangan kebijakan, dan dokumen lainnya yang berhubungan dengan permasalahan penelitian.

\section{Potensi dan Arahan Kebijakan Pariwisata Daerah}

\subsection{Gambaran Potensi Wisata Kabupaten Katingan}

Berdasarkan RIPPDA Kabupaten Katingan, potensi wisata daerah dibagi ke dalam 3 kelompok utama, yaitu wisata alam, wisata budaya dan sejarah serta wisata minat khusus.

a. Wisata alam merupakan potensi wisata yang paling dominan di Kabupaten Katingan. Jenis wisata alam yang ada di Kabupaten Katingan antara lain meliputi Taman Nasional, Kebun Raya, wisata danau, wisata susur sungai, pemandian air panas, riam-riam, dan kawasan perbukitan yang bisa digunakan untuk kegiatan mendaki;

b. Wisata budaya dan sejarah terkait dengan keberadaan situs, bangunan, benda-benda warisan budaya/ cagar budaya, peninggalan sejarah masa lampau, serta berbagai macam bentuk dan jenis kearifan lokal suku Dayak seperti Rumah Betang, Bangunan Sapundu, ragam upacara adat, Festival Budaya Daerah dan lain sebagainya; dan

c. Wisata minat khusus terkait dengan kegiatan wisata yang menyasar pasa khusus seperti kelompok pecinta alam dan petualang yang umumnya kegiatannya meliputi antara lain kegiatan ekspedisi dan eksplorasi.

\subsection{Aksesibilitas dan Sarana Prasarana}

Infrastruktur utama di Kabupaten Katingan yaitu berupa jalan darat (jalan beraspal, jalan non-aspal) dan jalan sungai yang menjadi penghubung antar wilayah. Alat transportasi darat yang tersedia adalah alat angkutan umum, bis, rent car dan mobil travel, sementara itu untuk untuk alat transportasi air menggunakan kapal motor, speedboat, longboat, kelotok perahu dan kapal penumpang (dengan rute khusus). Sementara itu fasilitas akomodasi yang ada di Kabupaten Katingan antara lain berupa hotel non bintang, losmen, penginapan, guest house, yang tersebar di beberapa wilayah, khususnya di wilayah perkotaan/ ibukota kecamatan. Fasilitas penunjang lainnya yaitu berbagai usaha yang dikategorikan sebagai usaha wisata seperti rumah makan, café, mini market/ toko, penjualan souvenir, terminal, pelabuhan, sarana pintu masuk/ gerbang dan shelter (untuk lokasi wisata tertentu), toilet umum, dan pusat informasi.

\subsection{Rencana Tata Ruang Wilayah Kawasan Budidaya Sektor Pari- wisata}

Pemerintah Kabupaten Katingan telah membuat Rancangan Peraturan 
Daerah tentang Rencana Tata Ruang Wilayah Kabupaten Katingan yang mencakup penetapan alokasi luasan wilayah untuk pembangunan sektor pariwisata daerah yang termuat dalam Rencana Pola Ruang Kawasan Budidaya. Kawasan budidaya yang ada di Kabupaten Katingan, selain difungsikan sesuai peruntukannya, dapat pula digunakan untuk menunjang pengembangan sektor pariwisata, antara lain yaitu (a) kawasan pertanian; (b) kawasan perkebunan; (c) kawasan industri termasuk berbagai sarana untuk mengembangkan industri yang berwawasan lingkungan serta memberikan kemudahan dan daya tarik bagi investasi dengan pendekatan konsep efisiensi, tata ruang, dan lingkungan hidup; dan (d) kawasan pariwisata yang tersebar secara merata di tiap kecamatan dengan luasan yang ditetapkan adalah sebesar \pm 6 .000 Ha yang meliputi kawasan wisata alam, kawasan wisata budaya, kawasan wisata sejarah, dan kawasan wisata buatan dengan masing-masing luasan diatur dalam ketentuan tata ruang khusus kawasan yang saat ini masih belum disusun.

\subsection{Arahan Kebijakan Pembangunan Pariwisata Daerah}

Arah kebijakan pembangunan pariwisata di Kabupaten Katingan sesuai dengan Rencana Pembangunan Jangka Menengah Daerah (RPJMD), RIPPDA dan Rencana Strategis Pembangunan Kabupaten Katingan Tahun 2013-2018 yaitu untuk (1) menetapkan dan membangun destinasi wisata unggulan daerah; (2) menetapkan masterplan dan siteplan untuk setiap lokasi wisata potensial; (3) meningkatkan publikasi pariwisata daerah; (4) meningkatkan penyediaan sarana dan prasarana utama maupun pendukung kegiatan kepariwisataan; (5) menjadikan pariwisata sebagai bagian dari kegiatan masyarakat dengan memfokuskan kepada pengembangan kreativitas dan inovasi yang berdaya guna; serta (6) meningkatkan kualitas kehidupan beragama dan ketahanan budaya yang dilaksanakan melalui pembangunan pada fungsi-fungsi tersebut.

\section{Analisis Kebijakan Pembangunan Pariwisata Kabupaten Katingan}

Kebutuhan akan pembangunan sektor-sektor yang mampu menciptakan peluang perekonomian yang baru, baik bagi masyarakat secara khusus maupun bagi perkembangan daerah secara umum merupakan salah satu dasar ditetapkannya sektor pariwisata sebagai sektor yang dibangun dan dikembangkan di Kabupaten Katingan. Kebijakan pembangunan kepariwisataan di Kabupaten Katingan disusun dalam suatu format tertulis berupa Rencana Induk Pembangunan Pariwisata Daerah (RIPPDA) yang pembuatannya menjadi kewenangan Bappelitbang Kabupaten Katingan. Pembuatan kebijakan yang melibatkan elemen-elemen terkait serta konsultan pariwisata, telah dijalankan sesuai dengan prosedur yang diatur dalam perencanaan pembangunan dengan mengacu pada Undang-Undang 


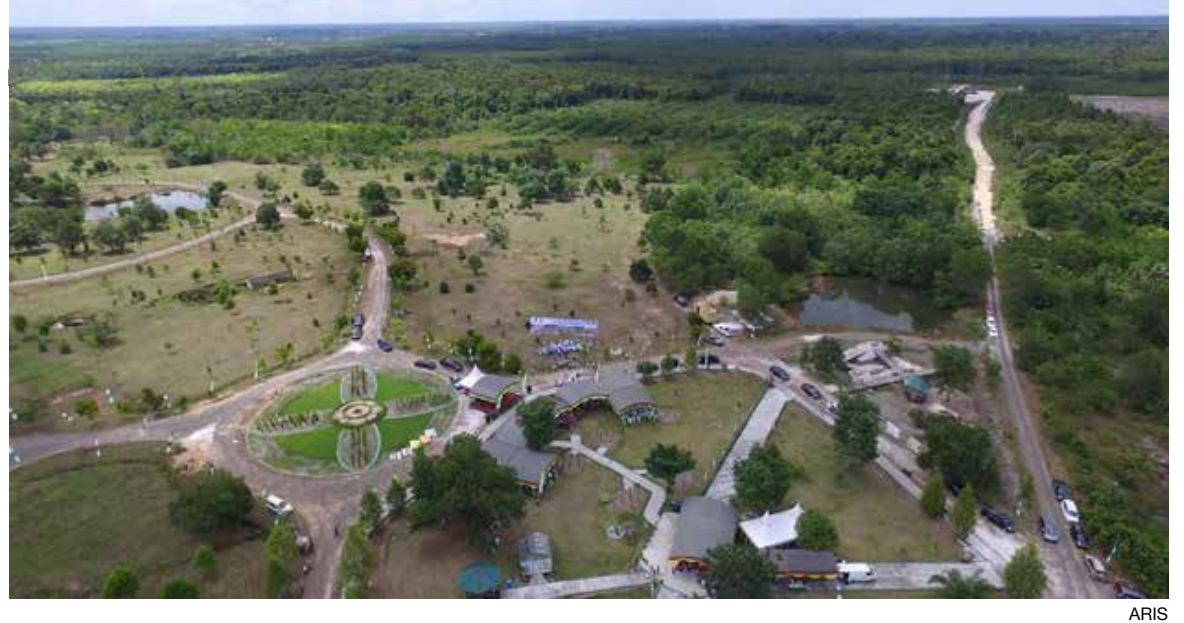

Foto 2. Kebun Raya Katingan sebagai potensi potensi ekowisata

Kepariwisataan, Rencana Induk Pembangunan Pariwisata Nasional serta kebijakan-kebijakan teknis lainnya.

Rencana Induk Pembangunan Pariwisata Kabupaten Katingan dirumuskan dengan mempertimbangkan beberapa aspek/ kriteria tertentu demi menjadikannya sebagai suatu kebijakan pembangunan yang efektif, sesuai dengan konsep pembangunan berkelanjutan serta arahan kebijakan nasional, sehingga dapat dilaksanakan dengan bertanggung jawab untuk menjawab kebutuhan masyarakat. Adapun aspek-aspek tersebut antara lain yaitu (1) aspek perencanaan pembangunan, (2) aspek lingkungan, (3) aspek sosial budaya, (4) aspek ekonomi, serta (5) aspek hukum dan kelembagaan. Hasil wawancara dan penelusuran data menunjukkan bahwa semua komponen dan kriteria kebijakan sudah dipenuhi serta dalam prosesnya sudah dijalankan sesuai dengan pedoman yang ada, akan tetapi keberadaan RIPPDA sebagai kebijakan yang mengatur mengenai pelaksanaan kegiatan pembangunan sektor pariwisata daerah masih belum mampu mendorong terlaksananya pembangunan yang memadai di daerah. Oleh karena itu dilakukan identifikasi terhadap berbagai kendala yang dihadapi dalam pembuatan kebijakan yang mempengaruhi proses maupun implementasinya di daerah.

\subsection{Identifikasi Permasalahan Kebijakan}

Berdasarkan hasil kajian terhadap proses pembuatan kebijakan pembangunan pariwisata di Kabupaten Katingan, terdapat berbagai permasalahan/ kendala yang dihadapi dalam mekanisme pembuatan kebijakan yang mempengaruhi proses maupun substansi kebijakan, antara lain yaitu (1) kedudukan pemerintah daerah dalam pelaksanaan wewenang otonomi masih memiliki ketergantungan yang tinggi terhadap pemerintahan pusat yang membatasi ruang gerak pemerintah daerah dalam menyusun kebijakan-kebijakan strategis yang sesuai dengan karakteristik daerah. Wewenang otonomi sebenarnya memberikan keleluasaan bagi daerah untuk 
dapat mengatur dan merancang pola pembangunan yang lebih efektif dengan menggali kreativitas dan menciptakan inovasi bukan hanya sebagai bentuk ketaatan birokrasi; (2) kajian terhadap aspek/ kriteria dalam pembangunan sejauh ini masih dijadikan sebagai dokumen pelengkap administrasi (prasyarat) untuk mengesahkan keberadaan RIPPDA, sementara itu penetapan prioritas utama untuk penggalian sumber daya potensial dan pemanfaatannya yang mengacu kepada kajian aspek-aspek tersebut belum tersedia, (3) gambaran yang tertuang dalam Rencana Tata Ruang Wilayah Kabupaten Katingan mengenai alokasi lahan untuk pembangunan sektor pariwisata masih merupakan gambaran umum yang perlu ditindaklanjuti dengan pembuatan perencanaan kawasan yang bersifat khusus, yang sampai dengan saat ini belum dilakukan oleh pemerintah daerah; (4) koordinasi dalam perencanaan pembangunan sektor pariwisata daerah masih sangat terbatas di dalam ruang lingkup kabupaten saja, belum ada bentuk koordinasi dengan daerah lainnya dalam ruang lingkup wilayah provinsi (regional); (5) infrastruktur/ aksesibilitas daerah secara umum masih belum memadai yang secara tidak langsung membatasi kegiatan-kegiatan perencanaan yang sangat tergantung dengan keberadaan infrastruktur; 6) tingkat keterlibatan masyarakat dan sektor usaha dalam perumusan kebijakan relatif rendah (khususnya dalam pembuatan RIPPDA yang sudah dilaksanakan), dan (7) kesenjangan pembangunan antar wilayah menjadi dilema dalam penentuan titik-titik pembangunan, sehingga program-program pembangunan lebih sering dirancang untuk dilaksanakan di wilayah-wilayah perkotaan yang relatif lebih mudah dijangkau.

\subsection{Implementasi Kebijakan dalam Upaya Pembangunan Pariwi- sata Daerah}

Pelaksanaan pembangunan sektor pariwisata daerah dikoordinir oleh Dinas Kebudayaan Pariwisata Pemuda dan Olahraga Kabupaten Katingan, yang memiliki tugas pokok dan fungsi sebagai pelaksana teknis sektor kepariwisataan dengan anggaran pembangunan yang bersumber sepenuhnya dari APBD Kabupaten Katingan. Dalam pelaksanaan kewenangan tersebut, pemerintah daerah menunjuk dan menentukan instansi pelaksana yang disebut Organisasi Perangkat Daerah (OPD) untuk menangani sektor-sektor sesuai dengan tugas pokok dan fungsinya dalam pelaksanaan pembangunan di daerah. Pembagian kewenangan yang termuat dalam tugas pokok dan fungsi masing-masing OPD tersebut diharapkan dapat menjadi pedoman dan arahan tindakan bagi pelaksanaan kegiatan pembangunan yang juga sekaligus memberikan informasi mengenai bentuk dan jenis koordinasi yang perlu dilakukan oleh tiap OPD.

Berdasarkan hasil kajian terhadap tahapan pelaksanaan kebijakan pembangunan pariwisata di Kabupaten Katingan yang mengacu pada teori 


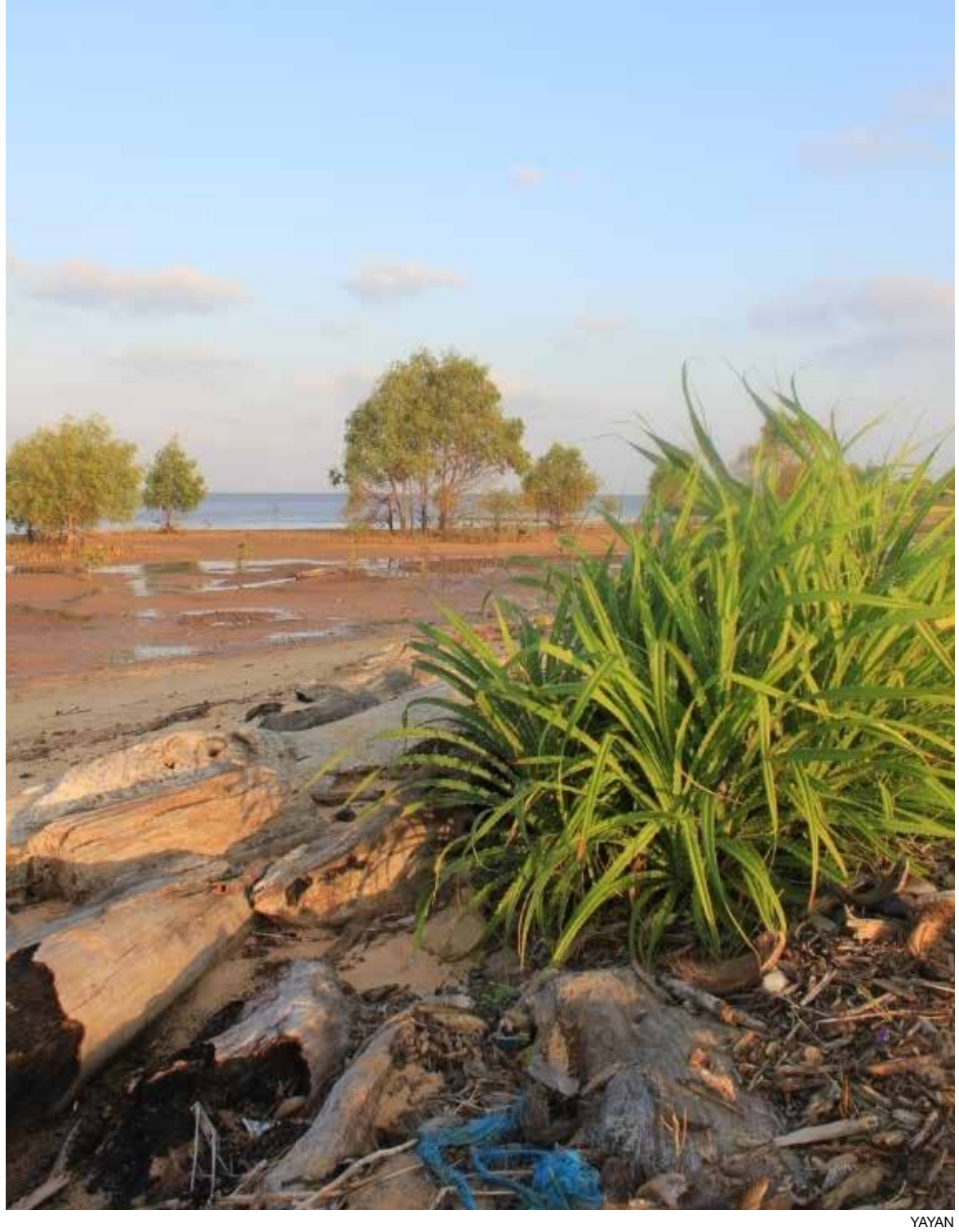

Foto 3. Pantai Pulau Damar di Katingan Kuala sebagai potensi wisata alam

kebijakan publikyang diungkapkan oleh Dunn (2003:22), upaya pelaksanaan kebijakan yang telah dilakukan yaitu (1) penyusunan agenda yang sejauh ini masih didasarkan pada kebijakan pemerintah pusat, (b) formulasi kebijakan yang dilakukan melalui pembuatan RIPPDA dan Renstra sektor pariwisata yang menjadi acuan bagi penyusunan kegiatan/ program operasional sektor pariwisata. Akan tetapi agenda kebijakan yang belum didasarkan pada kebutuhan masyarakat secara khusus, mengakibatkan timbulnya rumusanrumusan solusi yang juga bersifat umum yang tercermin dari kegiatan/ program yang ada saat ini, (c) adopsi kebijakan yang dilakukan melalui penyusunan dokumen RIPPDA, sementara itu legitimasi terhadap kebijakan pembangunan masih terbatas pada Dokumen Pelaksanaan Anggaran (DPA) yang tertuang dalam APBD sebagai dasar bagi pelaksanaan kegiatan/ 
program dalam kaitannya dengan penggunaan anggaran, (d) implementasi kebijakan terkait upaya penyelenggaraan pemerintahan dalam melaksanakan kegiatan/ program pembangunan sektor pariwisata baik sebagai kegiatan rutin tahunan maupun kegiatan/ program tertentu yang sudah diatur dalam Dokumen Pelaksana Anggaran, (e) pengendalian dan evaluasi kebijakan yang dilakukan sejak tahap penyusunan agenda sehingga menghasilkan rumusan kebijakan sampai dengan tahap implementasi kebijakan terkait penilaian terhadap pelaksanaan kegiatan yang antara lain disampaikan melalui Laporan Realisasi Anggaran (LRA) dan Laporan Kinerja (LAKIP). Sementara itu penilaian terhadap substansi kebijakan dilakukan antara lain melalui Musrenbang, public hearing maupun rapat-rapat khusus yang melibatkan DPRD Kabupaten Katingan.

\section{Rancangan Kebijakan Alternatif untuk Menunjang Pembangunan Pari- wisata di Kabupaten Katingan}

Analisis terhadap proses pembuatan maupun pelaksanaan kebijakan pembangunan pariwisata Kabupaten Katingan menunjukan bahwa kebijakan yang tertuang dalam rencana induk secara prinsip sudah mengatur ketentuan-ketentuan umum dalam hal kepariwisataan daerah serta proses perumusannya sudah sesuai dengan pedoman pembangunan nasional maupun regional. Mengacu pada pedoman yang sama, selanjutnya ketentuan (kebijakan) umum tersebut perlu untuk diuraikan lagi menjadi kebijakan yang bersifat khusus (teknis) sehingga dapat lebih efektif dalam pelaksanaannya, karena menyangkut ketentuan pelaksanaan operasional. Oleh karena itu penyusunan kebijakan teknis/ fungsional perlu untuk dilakukan sebagai salah satu upaya prioritas dalam perencanaan pembangunan pariwisata di Kabupaten Katingan.

Metode Regulatory Impact Analysis digunakan untuk merumuskan permasalahan kebijakan dan mengidentifikasi tujuan, yang menghasilkan rumusan/rancangan kebijakan alternatif untuk penanganan sektor pariwisata di Kabupaten Katingan. Berdasarkan hasil pengkajian terhadap dokumen kebijakan yang ada serta hasil wawancara, disimpulkan bahwa kebijakan pengelolaan potensi serta penataan kawasan merupakan upaya prioritas yang perlu diatur untuk menjamin sistem pengelolaan dan penataan sumber daya yang memadai. Selanjutnya dijabarkan masingmasing rancangan kebijakan yang diajukan sebagai rumusan kebijakan alternatif dalam pembangunan pariwisata di Kabupaten Katingan.

\subsection{Rumusan Kebijakan Pengelolaan Sumber Daya Lestari \& Kolaboratif}

Prinsip dalam pengelolaan potensi sumber daya pariwisata Kabupaten Katingan akan didasarkan pada prinsip pengelolaan sumber daya lestari dan 
kolaboratif, yang disesuaikan dengan visi daerah sebagai Pusat Konservasi Borneo untuk mewujudkan pembangunan yang berwawasan lingkungan serta menjadikan masyarakat sebagai mitra dalam upaya pengelolaannya, yang mencakup prinsip (1) pengelolaan fungsi sumber daya yang beorientasi pada ketentuan atau pengaturan mengenai fungsi dasar/ utama sumber daya untuk mengoptimalkan produktivitasnya; serta (2) pengelolaan manfaat dan hasil sumber daya yang berorientasi pada ketentuan/ aturan mengenai hasil-hasil sekunder dari sumber daya serta kajian terhadap manfaat sumber daya bagi lingkungan sekitar. Rancangan ini ke depannya diarahkan untuk melahirkan langkah atau upaya strategis mengenai penanganan potensi sumber daya pariwisata daerah yang dimulai dari pengelolaan potensi sumber daya biasa sampai menjadi sumber daya pariwisata yang akan terus menerus dilakukan secara berkelanjutan. Pengelolaan potensi pariwisata yang dibuat dengan mengacu pada prinsip fungsi dan manfaat masing-masing dihubungkan dengan aspek utama dalam pembangunan berkelanjutan. Dalam pengelolaan potensi yang berlandaskan prinsip fungsi ini akan diatur mengenai pengelolaan sumber daya untuk optimalisasi produktivitasnya sesuai dengan fungsi utamanya, sehingga dapat tetap memenuhi kebutuhan masyarakat maupun lingkungan. Penerapan prinsip ini akan memberikan ruang yang besar bagi aspek lingkungan/ ekologi dan sosial dengan dampak yang relatif kecil terhadap aspek ekonomi, oleh karena itu pelaksanaan kegiatan pengelolaan harus dilengkapi dengan penerapan prinsip manfaat yang akan memberikan arahan mengenai bentuk optimalisasi pemanfaatan sumber daya yang bisa memberikan dampak ekonomi bagi masyarakat.

\subsection{Rumusan Kebijakan Penetapan dan Penataan Kawasan/ Lo- kasi Wisata}

Penataan kawasan/ lokasi wisata di Kabupaten Katingan diarahkan untuk menjadi penataan kawasan yang berwawasan lingkungan sehingga bisa mencapai pola penataan ruang yang berkualitas, yang mampu melindungi segenap keberadaan ekosistem, serta mampu menunjang kehidupan sosial dan ekonomi masyarakat. Penataan kawasan juga dilakukan untuk menjamin fungsi dan manfaat kawasan yang berkelanjutan sehingga bisa menjaga keseimbangan antara bentuk pemanfaatan dengan bentuk pelestariannya. Model/ rancangan yang diajukan terkait kebijakan penataan kawasan ini mencakup tiga pokok kegiatan utama, yaitu perencanaan ruang, pemanfaatan ruang dan pengendalian pemanfaatan ruang. Berdasarkan rencana tata ruang Kabupaten Katingan ditetapkan luasan kawasan fungsional/ budidaya untuk sektor pariwisata dengan besaran yang merata bagi tiap kecamatan yaitu seluas \pm 6.000 Ha yang juga disertai dengan peluang pemanfaatan kawasan budidaya lainnya yang bisa diintegrasikan dengan sektor pariwisata. 
Saat ini kawasan yang sudah mulai dibangun berada di ibukota Kabupaten (Kecamatan Katingan Hilir) serta di wilayah terjauh yang mencakup wilayah Taman Nasional (Kecamatan Bukit Raya). Rancangan pengaturan mengenai pemanfaatan kawasan mencakup ketentuan pokok yaitu antara lain mengenai (1) penentuan peruntukan lahan/ tata guna lahan dan penataan ruang-ruang wilayah sesuai kebutuhan dan fungsinya serta penyiapan terhadap kemungkinan adanya alih fungsi lahan; (2) penataan dan pembagian zona-zona khusus dalam suatu kawasan/lokasi wisata, seperti zona kunjungan publik, zona perlindungan, zona layanan umum, maupun zona pendukung/ penunjang kawasan lainnya; (3) pembangunan dan pengelolaan berbagai sarana prasarana utama maupun penunjang di dalam maupun di sekitar kawasan wisata sesuai dengan peruntukannya; (4) pengaturan mengenai akses publik dan atau akses khusus, ruang publik beserta jalur-jalur akses dari, di dan menuju kawasan; (5) pembangunan dan penataan kawasan pengelolaan sampah dan limbah sehingga tidak mengganggu visual dan fisik lingkungan; (6) manajemen sumber daya yang digunakan dalam pembangunan maupun dan operasional kawasan untuk menjamin perlindungan dan pelestarian sumber daya lingkungan; serta (7) pengembangan berbagai kegiatan perekonomian masyarakat melalui penataan kawasan wisata terpadu serta penetapan zona-zona kreatif.

Rumusan upaya strategis dalam pengendalian pemanfaatan ruang yang difungsikan sebagai kawasan/ lokasi wisata yang bisa dilakukan antara lain yaitu (1) pembentukan tim koordinasi khusus sebagai pengawas aktivitas pemanfaatan ruang dengan berpedoman pada ketentuan dan kriteria yang sudah diatur; (2) sosialisasi dan pelaksanaan kegiatan konservasi dan penanaman pohon/ penghijauan, reboisasi maupun rehabilitasi lahan sebagai kegiatan rutin pemerintah dengan melibatkan unsur-unsur terkait di daerah; (3) pengendalian terhadap bentuk dan pola pemanfaatan sumber daya, terutama sumber daya yang tak terbarukan; (4) penyusunan dan pelaksanaan program normalisasi sungai serta pembangunan fasilitas pengendali banjir; (5) pengawasan terhadap kegiatan pembangunan, termasuk pengawasan terhadap penggunaan material dari dalam maupun dari luar kawasan terkait kesesuaian dengan kriteria yang sudah diatur; (6) manajemen limbah/ sampah; (7) menjalin kerjasama dengan masyarakat maupun pelaku usaha untuk melaksanakan kegiatan Corporate Social Responsibility secara rutin; serta (8) melakukan kajian dan penilaian (evaluasi) terhadap pelaksanaan pemanfaatan ruang dalam pencapaian tujuan rencana tata ruang wilayah secara keseluruhan.

\section{Simpulan dan Saran}

Potensi sumber daya pariwisata yang dimiliki Kabupaten Katingan membutuhkan campur tangan pemerintah daerah sebagai pemrakarsa dan 
pelaksana pembangunan di daerah agar mampu merancang upaya strategis melalui kebijakan-kebijakan yang dibuat. Pemerintah Kabupaten Katingan sudah menyusun RIPPDA sebagai salah satu upaya dalam pembangunan sektor pariwisata akan tetapi keberadaan RIPPDA belum mampu mendorong terlaksananya pembangunan pariwisata daerah selain hanya dijadikan sebagai salah satu dasar bagi penyusunan kegiatan/ program dinas terkait. Selain itu juga terdapat berbagai kendala dan permasalahan terkait dengan pelaksanaan kewenangan pemerintah daerah yang mengakibatkan pencapaian sasaran kebijakan tidak tercapai. RIPPDA sebagai kebijakan yang bersifat umum perlu ditunjang melalui kebijakan yang bersifat khusus yang digunakan untuk mengatur hal-hal teknis/ operasional terkait dengan pembangunan sektor pariwisata daerah. Akan tetapi sampai dengan saat ini kebijakan tersebut masih belum dibuat oleh instansi terkait, sehingga belum ada upaya penanganan terhadap keberadaan potensi sumber daya pariwisata daerah.

Kebijakan alternatif yang disusun berdasarkan permasalahan yang terjadi di Kabupaten Katingan diharapkan dapat menjadi rekomendasi dalam penentuan upaya prioritas yang perlu dilakukan oleh pemerintah daerah dalam penanganan sumber daya pariwisata agar bisa menjadi daya tarik wisata yang bernilai. Kebijakan pengelolaan potensi sumber daya yang didasarkan pada prinsip fungsi dan manfaat akan membuka peluang pemberdayaan sumber daya yang berkelanjutan yang ditunjang dengan kebijakan penataan kawasan yang berwawasan lingkungan yang memberikan peluang bagi pemanfaatan ruang-ruang publik dan kawasan fungsional maupun budidaya yang mengedepankan aspek lingkungan yang lestari sesuai dengan visi lingkungan Kabupaten Katingan sebagai wilayah Konservasi Borneo.

\section{Ucapan Terima Kasih}

Penulis mengucapkan terima kasih yang sebesar-besarnya kepada Prof. Dr. Ir. Syamsul Alam Paturusi, MSP selaku Dosen Pembimbing I dan Dr. Dewa Putu Oka Prasiasa, A.Par, M.M selaku dosen pembimbing II yang telah meluangkan waktu dengan teliti dan sabar untuk membantu, mendukung, membimbing dan memberikan arahan selama penelitian maupun untuk penyempurnaan tulisan ini. Penulis juga ingin menyampaikan rasa terima kasih dan hormat yang mendalam kepada Prof. Dr. I Nyoman Darma Putra, M. Litt. selaku Ketua Program Studi Magister Kajian Pariwisata Universitas Udayana yang telah memberikan kesempatan, bimbingan dan arahan sehingga penulis dapat menjalani pendidikan dengan baik serta termotivasi untuk melaksanakan penelitian dan menyelesaikan tulisan ini. Prof. Made Sudiana Mahendra, Mapp. Sc. Ph.D, Ir. A.A.P Pt. Agung Suryawan, W., M.Sc., Ph.D., dan Dr. Putu Tuni Cakabawa Landra, SH., M.H. yang telah 
memberikan banyak masukan, pertimbangan, saran, maupun koreksi untuk menyempurnakan tulisan ini. Bupati Katingan, Sekretaris Daerah Kabupaten Katingan dan Kepala Dinas Kebudayaan Pariwisata Pemuda dan Olahraga Kabupaten Katingan yang telah memberikan kesempatan dan restu bagi penulis untuk dapat menempuh pendidikan lanjutan maupun ijin untuk melaksanakan penelitian di Kabupaten Katingan, serta kedua orang tua terkasih, seluruh keluarga, seluruh informan dan pihak-pihak yang senantiasa mendukung dan memberi motivasi bagi penulis dalam menyelesaikan tulisan ini.

\section{Daftar Pustaka}

Agustino, Leo. 2009. Pilkada dan Dinamika Politik Lokal. Yogyakarta: Pustaka Pelajar.

Bhuiyan, Anowar H Md., Chamhuri Siwar., Shaharuddin Muhammad., \& Rabiul Islam. 2011. "The Role of Government for Ecotourism Development: Focusing on East Coast Economic Region”, Journal of Social Sciences. 7 (4): pp. 557-564.

Birkic, Drazenka., Ida C. Pilija., \& Jelena K. Sebrek. 2014. 'The Role Of Local Government In Planning Sustainable Tourism Of Coastal Destination', Tourism and Hospitality Industry Scientific Paper. 1 (2): pp. 16-31.

Brokaj, Rezarta. 2014. "Local Government's Role In The Sustainable Tourism Development Of A Destination”, European Scientific Journal. Vol. 10, No. 31, pp. 103-116.

Cohen, John M., \& Norman T. Uphoff. 1980. "Participation's Place in Rural Development: Seeking Clarity Through Specificity” World Development. Vol. 8, issue 3. pp 213-235.

Conyers, Diana., \& Peter Hills. 1984. An Introduction to Development Planning in The Third World. New York: John Willeys \& Sons.

Conlin, Michael V. \& Tom Baun. 1995. Island Tourism Management Principles and Practices. Great Britain: Biddles Ltd, Guildford and King's Lyn.

Dunn, William N. 2003 Analisis Kebijakan Publik. Yogyakarta: Gadjah Mada University Press.

Gorica, Klodiana., Dorina Kripa \& Engjellushe Zenelaj. 2012. "The Role Of Local Government in Sustainable Development", Acta Universitatis Danubius. Vol. 8, No 2, pp. 139-155.

Hadjon, Philipus M. 2002. Pengantar Hukum Administrasi Indonesia. Yogyakarta: Gadjah Mada University Press.

Jupir, Maksimilianus M. 2013. "Implementasi Kebijakan Pariwisata Berbasis Kearifan Lokal (Studi di Kabupaten Manggarai Barat)", Journal Of Indonesian Tourism and Development Studies. Vol. 1 No. 1, pp: 28-37.

Moleong, Lexy J. 2012. Metodologi Penelitian Kualitatif Edisi Revisi. Bandung: Remaja Rosda.

Munir, B. 2002. Perencanaan Pembangunan Daerah Dalam Perspektif Otonomi 
Daerah. Bappeda Provinsi NTB.

Nugroho, Riant. 2009. Public Policy (edisi revisi). Jakarta: PT. Elex Media Komputindo.

Nurhayati, Alfisah. 2010. "Revisiting Pariwisata Madura: Studi Kebijakan Pembangunan Kepariwisataan Kabupaten Sampang”, E- Journal Karsa. Vol. XVIII, No. 2, pp. 183-192.

Peraturan Pemerintah Nomor 8 Tahun 2008 tentang Tahapan, Tata Cara Penyusunan, Pengendalian dan Evaluasi Pelaksanaan Rencana Pembangunan Daerah.

Peraturan Pemerintah Republik Indonesia Nomor 50 Tahun 2011 Tentang Rencana Induk Pembangunan Kepariwisataan Nasional Tahun 2010-2025.

Pitana, I Gede dan Putu G. Gayatri. 2005. Sosiologi Pariwisata. Yogyakarta: Andi.

Rasyid, Ryaas. 2002. Otonomi Daerah: Latar Belakang dan Masa Depannya dalam Syamsudi Haris (ed). Desentralisasi, Demokratisasi, dan Akuntabilitas. Jakarta: AIPI dan Partnership.

Undang-Undang Republik Indonesia Nomor 10 Tahun 2009 Tentang Kepariwisataan. Undang-Undang Republik Indonesia Nomor 23 Tahun 2014 Tentang Pemerintahan Daerah.

O’Toole, L.J. 2000. "Research on Policy Implementation: Assesment and Prospect", Journal Of Public Administration Research and Theory, 10 (2), pp. 263-288. Wahab, Saleh. 2003. Manajemen Kepariwisataan. Jakarta: Pradnya Paramita. Yoeti, Oka A. 1996. Pengantar Ilmu Pariwisata. Bandung: Aksara.

Yoeti, Oka A. 1997. Perencanaan dan Pengembangan Pariwisata. Jakarta: Pradnya Paramitha.

\section{Profil Penulis}

Emelyn Novalisa adalah Aparatur Sipil Negara (ASN) yang bekerja di Dinas Kebudayaan Pariwisata Pemuda dan Olahraga Kabupaten Katingan, Provinsi Kalimantan Tengah. Menyelesaikan program Sarjana (S1) di Fakultas Ekonomi Jurusan Manajemen Pariwisata Universitas Kristen Petra, Surabaya pada tahun 2011, dan Program Studi Magister Kajian Pariwisata (S2) di Universitas Udayana, Denpasar pada tahun 2017. Email: lisa.emelynnova@yahoo.com;

Syamsul Alam Paturusi adalah guru besar Fakultas Teknik Unud yang saat ini menjabat sebagai Sekretaris Program Studi Magister Kajian Pariwisata Unud. Selain itu juga aktif mengajar di beberapa program studi di Universitas Udayana diantaranya pada Program Teknik Arsitektur dan Ilmu Lingkungan. Dia menerima gelar Guru Besar dalam "Perancangan Kota” Fakultas Teknik Universitas Udayana pada tahun 2017. Meraih Gelar Doktor ( $\mathrm{S}_{3}$ ) di Universite` de Pau et des Pays de l'Adour, Prancis pada tahun 2000. Gelar Magister (S2) Perencanaan Wilayah dan Kota (PWK) di Institut Teknologi Bandung pada tahun 1988. Gelar Sarjana (S1) pada Jurusan Arsitektur Universitas Hasanuddin Makassar pada tahun 1983. Email: syamsul_alam_paturusi@yahoo.fr; 
Dewa Putu Oka Prasiasa meraih gelar Doktor Kajian Budaya Konsentrasi Pariwisata dari Universitas Udayana, 2010. Gelar Magister Manajemen Konsentrasi Pemasaran Pariwisata dari Universitas Sahid Jakarta, 2000. Sebelumnya menyelesaikan Program Diploma 4 Pariwisata dari Universitas Udayana, 1993. Sekarang tercatat sebagai Dosen PNS Kopertis VIII Bali ditempatkan pada Sekolah Tinggi Ilmu Manajemen Indonesia (STIMI) Handayani, Denpasar. Sejak 2012 sebagai Dosen Tidak Tetap Program Magister Kajian Pariwisata Universitas Udayana. Buku-buku yang sudah diterbitkan di antaranya Wacana Kontemporer Pariwisata (2011) dan Destinasi Pariwisata Berbasis Masyarakat (2013). Tahun 2012 sebagai Editor buku Pengembangan Wisata Bahari di Indonesia yang diterbitkan oleh Puslitbang Kebijakan Kepariwisataan Kementerian Pariwisata dan Ekonomi Kreatif Republik Indonesia. Email: oka.dewaputu@yahoo.com dan dewaputuoka18@gmail.com. 